\title{
Psalms, part 2, and Lamentations (Forms of the Old Testament Literature Volume XV)
}

\author{
by Erhard S Gerstenberger
}

Grand Rapids: William B Eerdmans

August 2001

p. $x x i i+543$

ISBN 0802804888

Price $\$ 45$

\section{Reviewed by Jan P Bosman}

Qerstenberger's commentary on Psalms 61-150 (Book 2-5) of the Psalter and Jamentations follows his 1988 commentary on Psalms 1-60 (Psalms, Part 1; with an introduction to cultic poetry - FOTL XIV) which included a very important section on cultic poetry. The two volumes should ideally be studied together as Part 2 frequently refers back to especially the section on cultic poetry in Part 1 . Part 1 also contains the general introduction to the Psalter where Gerstenberger discusses the growth and history of the Psalter and proposes his main premises. Part 2 is a form-critical commentary in line with the stated goals of the FOTL series to give a 'form-critical analysis of every book and each unit of the Old Testament ... [to] expose the exegetical procedure in such a way as to enable students and pastors to engage in their own analysis and interpretation' (xii). Gerstenberger successfully complies with these goals by giving an extensive (traditional) form-critical analysis of Psalms 61-150 and Lamentations, involving attention to theology and poetic language. He continues on what Petersen (1992:32) called his 'innovative course' and 'fresh approach to ritual.' Like in Part 1 Gerstenberger's main premise is that the 'final converging point of collecting and redactional activities' of the psalms should be sought in the "worship ceremonies of the early Jewish communities of the sixth to second centuries B.C.E.' (xv). To him the God of the Psalter is therefore 'mostly the God of exilic and postexilic Israel' (xv). The cult, liturgy and ritual practice inform his research as well as the maxim that the social context of texts should be respected as 'texts are not freelancing autonomous powers, but belong to determined people' (xvi).

The commentary contains forewords by both the editors and the author containing a clear communication of the goals and methodological decisions under girding the series and the specific commentary. An extensive bibliography follows, including valuable resources on 'Cultic poetry and ceremony' (xviii). Apart from the main bibliography, each psalm has its own specialized bibliography. In the Psalms commentary Gerstenberger stays with the traditional five-book division of the Psalter and treats each "Book" (books 2-5) as separate "chapters" of the unified work. The form-critical categories of analysis, namely, Text, Structure, Genre, Setting and Intention are used to present the research on each of the separate psalms as well as on the five books of Lamentations. So, e.g., in Ps 61 he identifies elements of 'invocation,' 'petition,' 'affirmations of confidence,' 'vows' etc. and sees the genre of the psalm as a whole as a 'congregational Psalm of confidence, derived from the pattern of the complaint of the individual' (6). The commentary on Lamentations follows along the same vein, including introductory remarks on the History (467), Meter and literary forms (470), Contents and purpose (471), Historical situations and social roots (473) and Theology and ethics (475) of, what Gerstenberger calls the 'booklet.' The book ends with a glossary (506ff.) containing definitions of genres and formulae. The 
commentary is worth having just for the excellent glossary which describes technical theological, literary and "psalmic" terminology. Especially helpful are the many translations and definitions of German theological expressions and technical formulae. Gerstenberger serves as a mediator between the English and German theological worlds. This glossary and the forthcoming FOTL volume Glossary of genre terms (Knierim, RP \& Tucker, GM (eds), FOTL XXII) are important guides in the sometimes confusing academic theological language.

Some of Gerstenberger's most important premises in his reading of the Psalter and Lamentations are first, the focus on the cultic/ ritual/ liturgical setting of (all) the psalms in the exilic/ postexilic time. Gerstenberger makes a case for the separation of Israel's exilic/ postexilic religion into small group settings (usually family cult) against State religion settings (the bigger Jewish assemblies). His conviction of the primacy of the liturgical/ cultic setting of the psalms that he sometimes uses this (not always agreed on) fact that most psalms' final version stems from liturgical settings in the exilic/postexilic times as arguments for a certain interpretation. The genre of Ps 61, e.g., has 'to be decided on liturgical considerations' (7) and the apparent heterogeneous and oversized nature of Ps 89 becomes a cohesive whole ' $[\mathrm{I}] \mathrm{f}$ one sets it in the context of liturgical procedures within the community worship of the exilic or postexilic age' (154). This strong emphasis on the liturgical or communal setting can become a circular argument, e.g. the remark on Ps 128, 'If then, Psalm 128 was part of communal liturgy (and otherwise it would not be part of the Psalter) ...' (351). Furthermore the setting(s) of the different psalms sometimes are just too detailed (e.g. 'multiple liturgical groups singing different passages' of Ps147; p. 446) for a subject about which we know very little, and sometimes so vague that it could mean anything (e.g. Ps 74's setting as 'some day of mourning', p. 80). Be it as it may, Gerstenberger's approach is fresh and excites many questions and new avenues for research.

Secondly, the use of the texts in their social settings is important (e.g. Ps 102, p. 214). In the category "Intention" of the psalms he focuses sharply on the function the psalm would have had (and possibly still has) in the Israelite (and modern) faith communities. Thirdly, his form-critical discussion of the "structure" of each Psalm is brilliant. His dense intertextual (biblical and ancient Near Eastern) comments and examples (e.g. the 'Hymn to the Aton' Ps 104, p. 224) are extremely rich and helpful (although the dense style of writing and many references in brackets does not always make for smooth reading). Fourthly, he only discusses text-critical matters and questions in so far as it bears upon form-critical consequences. Fifth, he integrates grammatical notes, critical focusing questions, and modern anthropological research on ritual and critical engagement in important academic debates in a condensed meaningful manner. Sixth, he does not take the supposed unity of the Psalter too seriously, saying that 'holistic' readers of the Psalter pay too much attention (in his opinion) to the very late redactional division of the canonical collection and that redactional activities, 'were not able to thoroughly mold transmitted texts to interconnect them and give them new meaning' (252). Lastly, he often uses examples from present day faith communities and especially contextual experiences from the so-called Third World to inform his understanding of the psalms. For example, he refers to "base communities in the slums of Third World countries' (121-122) and 'Latin American liberation theology' (441). Interesting is, e.g., Ps 87's 'intention' as 'to clear the way for foreigners to take part in the ceremonies' - apparently to keep strangers on an inferior level (140) and Ps 119's genre being described as a 'Portrait of a Yahweh confessor' (316).

Lamentations (Heb. 'êkāh; Grk./Lat. Threnoi (tears) or qînôt (laments)) discusses the 'booklet's' five 'books' in the same form-critical categories of the Psalms. The discussion 
of the 'history' of Lamentations leads to the conclusion that, 'Lamentations probably originated in specific observances of mourning in the exilic and postexilic periods of Judean or Babylonian communities' (468), and that although there are ancient Near Eastern transcultural traditions of dirges and lamentations, a direct dependence of the OT can 'hardly be proven' (469). The 'Meter and literary forms' contains information on the use of acrostics, as well as the most important debates in Lamentation research (e.g., ancient Near Eastern dependency, the use of wisdom texts in worship and the problem of meter in Hebrew poetic texts) (468-470). The 'Contents and purpose' points to the generalized language and allusions to enemies, the highly organized form of the five texts 'revolving around the sufferings of Yahweh's city and her inhabitants,' the dramatized performance of theodicy and the fact that we do not find abstract theological clarifications but that the book, 'wants to alleviate acute consequences of war, terror, and oppression' (471-472). Gerstenberger sees Lamentations as not a historical report but the "liturgical shape of ceremonial mourning' (473) and looks at the 'Theology and ethics of God as a 'scornful deity' (475).

Gerstenberger points to the main metaphor of Israel as the bride of Yahweh (and discusses the offensiveness of it for modern readers in a gender sensitive way p. 481), uses the Psalms as important intertexts (495), accentuates the performance character of the laments (491) and the liturgical and communal/ congregational setting (502) as well as the ritual practice of biblical prayers (482-483). Ancient Near Eastern laments are also brought into play (e.g., Mesopotamia in Lam 1:20-22, p. 482; Sumeria's 'Immal Gudede' in Lam 2, p. 486). He speaks about messianism in Persian times (499) and the 'up and down' movement of Lament ceremonies with praise interdispersed 'between hope and despair' (495). Interesting points are, e.g., the idea that 'ch. 3 is possibly stressing the male sufferings in connection with the destruction of a city, while chs. 1 and 2 concentrate-more on female perspectives' (496), and the 'educational interest' that these 'commemorative liturgies' had (497).

In general the criticism would be regarding form-criticism as exegetical venture, with problems like 'What is genre?' Structure?' 'Setting?' etc., questions already asked since the boom of form criticism and the birth of the FOTL series in the 1960s (cf. Petersen's review of the FOTL series, 1992:30). These same questions surface in reading Gerstenberger's commentary (e.g. the apparent fluidity of the form-critical categories - sometimes even combined). More specifically, Gerstenberger's biggest contribution (the liturgical exilic/postexilic focus) also conjures up the most questions and problems. In summary, Gerstenberger shows his profound insight in the psalms and their role in Israelite religion. His sensitivity to the Third World, gender-issues and modern worship, and the way in which he integrates dense form-critical remarks, intertexts, a fresh approach to old questions, the bibliographical instruments and the glossary makes this commentary a very important contribution to the study of the Psalter.

\section{Bibliography}

Petersen, DL 1992. Hebrew Bible form criticism. Religious Studies Review 18/1, 29-33. 